\section{Evaluation of Transient, In-season Applied Heat to 'Merlot' and 'Syrah' Wine Grapes in Eastern Washington}

\author{
Hemant L. Gohil ${ }^{1}$ and Michelle M. Moyer ${ }^{2,3}$
}

ADDITIONAL INDEX WORDs. Vitis vinifera, canopy temperature manipulation, cluster temperature manipulation

SUMMARY. Sufficient heat accumulation is critical for fruit ripening in wine grape (Vitis vinifera). In 2013, a directed-heat application machine was evaluated for its ability to abridge vine phenology and improve fruit quality in commercially grown 'Syrah' and 'Merlot' in Paterson, WA. Heat was generated through the propane burning and applied to the vine via angled vents. The heat-generator was pulled by a tractor operating at $4 \mathrm{mph}$, resulting in a 2 -second exposure of heat per vine. Rows were treated on a weekly to biweekly basis with transient heat treatments during: 1 ) bloom only, 2) véraison only, 3 ) both bloom and véraison, 4) from budbreak to harvest, and 5) a no-heat applied control. Data collected included the timing of phenological stages, percent fruit set, duration and level of heat exposure of the fruit and canopy, juice soluble solids, titratable acidity (TA) and $\mathrm{pH}$ at commercial maturity. Air temperature at the vent blower was $\approx 300^{\circ} \mathrm{F}$; however, by the time the air reached the canopy, air temperature was $\approx 130$ to $150{ }^{\circ} \mathrm{F}$. As a result, the typical increase in leaf or cluster temperature was 10 to $20^{\circ} \mathrm{F}$ for 10 to $20 \mathrm{~s}$. Heat application did not increase the number of berries per cluster or fruit set, did not enhance or abridge key vine phenological stages, did not increase soluble solids concentration accumulation, and did not alter juice TA or $\mathrm{pH}$. Results indicate that heat application of this form does not advance vine phenology and in-field measured aspects of fruit quality in climates with large day-night temperature changes such as those in eastern Washington.

W ine quality is intrinsically tied to the quality of fruit provided for processing (Jackson and Lombard, 1993). Quality parameters typically measured in wine grapes are concentration of soluble solids, which determines final sugar and alcohol levels in wine; TA, which influences perception of acidity to the taster; and wine $\mathrm{pH}$ which can influence aging potential (Jackson, 2008). Additional factors that can influence final fruit "quality" are color

Support for this project was provided by Washington Wine Advisory Board, Altria Group, Inc., Ste. Michelle Wine Estates and the Washington State University (WSU) Viticulture and Enology Program; vineyards were provided by Columbia Crest Estate Vineyard (Paterson, WA)

We thank Ryan McAdams, Bill Riley, Bill Thompson, and Juan Uribe from Ste. Michelle Wine Estates for their technical assistance and Steve Hoff for his technical support. We also thank Julie Tarara (USDA-ARS), Rita Hummel, Yun Zhang and Lynn Mills (WSU) and Bill Riley for their thoughtful manuscript reviews.

${ }^{1}$ Viticulture and Enology Program, Washington State University-Irrigated Agriculture Research and Extension Center, Prosser, WA 99350

${ }^{2}$ Department of Horticulture, Washington State University-Irrigated Agriculture Research and $\mathrm{Ex}-$ tension Center, Prosser, WA 99350

${ }^{3}$ Corresponding author. E-mail: michelle.moyer@ wsu.edu. (anthocyanins), tannins and phenolics, and aromatic volatiles (Jackson and Lombard, 1993).

The rate of ripening in grape berries is controlled dominantly by the interaction of time and temperature during the growing season (Keller, 2010), so much so, that classification systems for site-appropriateness for different grape varieties tend to rely heavily on heat accumulation during the growing season (Amerine and Winkler, 1944; Jackson and Cherry, 1988; Yau et al., 2014). The accumulation of anthocyanins is also related to heat. Higher temperatures, independent of sun exposure during véraison result in reduced color accumulation (Spayd et al., 2002). Similar results are seen with TA. An increase in juice $\mathrm{pH}$ is also associated with an increase in heat exposure (Spayd et al., 2002).

The inland Pacific northwestern United States, particularly eastern Washington, is a fast-growing region for wine and wine grape production; it is second in the United States only to California (U.S. Department of Agriculture, 2013). The region is typified by the risk for cold damage during the dormant season (Ferguson et al., 2011), dry summers with average annual rainfall of 7.15 inches (AgWeatherNet, 2014), warm summers with average monthly high temperatures from June to August of 77.5 to $88.3{ }^{\circ} \mathrm{F}$ (AgWeatherNet, 2014; Yau et al., 2014), and average daylengths of 14 to $15.75 \mathrm{~h}$ between June and August. This semiarid climate provides sufficient heat units to adequately ripen the varieties being grown there. However, sugar accumulation during the ripening period may be delayed by large diurnal temperature changes of upwards of $30^{\circ} \mathrm{F}$ (AgWeatherNet, 2014). This delay can sometimes make it challenging to meet contract soluble solid specifications, which are typically between $24 \%$ and $28 \%$ for red wine grape varieties, before the first killing frost of the fall. Since natural maximum sugar accumulation is $\approx 25 \%$ (Keller, 2010), higher soluble solids concentration is generally due to dehydration; thus, extended hang time, preferably during warm, dry conditions, is necessary.

A machine patented in 2003 , which applies heated air to plants, is currently being marketed to wine grape growers with the intention of improving fruit set, wine quality, and controlling diseases and pests (Agrothermal Systems, 2013). The relevant questions to pose are whether increasing the fruit's exposure to short periods of heat during the growing season and through véraison could 1 ) override these potential limiters on ripening, 2) advance vine phenology and potential harvest date, 3 ) increase

\begin{tabular}{llll}
\hline $\begin{array}{l}\text { Units } \\
\begin{array}{l}\text { To convert U.S. to SI, } \\
\text { multiply by }\end{array}\end{array}$ & U.S. unit & SI unit & $\begin{array}{l}\text { To convert SI to U.S., } \\
\text { multiply by }\end{array}$ \\
\hline 1 & $\%$ & $\mathrm{~g} / 100 \mathrm{~mL}$ & $\mathrm{l}$ \\
0.4047 & $\mathrm{acre}(\mathrm{s})$ & $\mathrm{ha}$ & 2.4711 \\
0.3048 & $\mathrm{ft}$ & $\mathrm{m}$ & 3.2808 \\
2.54 & inch $(\mathrm{es})$ & $\mathrm{cm}$ & 0.3937 \\
1.6093 & $\mathrm{mph}$ & $\mathrm{km} \cdot \mathrm{h}^{-1}$ & 0.6214 \\
2.2417 & ton $(\mathrm{s}) / \mathrm{acre}$ & $\mathrm{Mg} \cdot \mathrm{ha}^{-1}$ & 0.4461 \\
$\left({ }^{\circ} \mathrm{F}-32\right) \div 1.8$ & ${ }^{\circ} \mathrm{F}$ & ${ }^{\circ} \mathrm{C}$ & $\left({ }^{\circ} \mathrm{C} \times 1.8\right)+32$
\end{tabular}


the potential soluble solids in fruit, or 4) enhance the fruit set and increase yield.

This field trial was designed to evaluate if this commercially marketed machine was able to increase fruit set, advance vine phenology, and improve final basic fruit quality metrics (soluble solids, $\mathrm{pH}$, and TA) through the use of transient, applied heat in commercially grown red wine grape varieties in irrigated eastern Washington.

\section{Materials and methods}

VINEYARD DESCRIPTION. The trial was located at a commercial vineyard (Ste. Michelle Wine Estates) near Paterson, WA (lat. $45.93^{\circ} \mathrm{N}$, long. $\left.119.60^{\circ} \mathrm{W}\right)$. The vineyard included a 55-acre block of 'Merlot' and a 30-acre block of 'Syrah' planted on own roots in 1997 and 1998, respectively. Vines were planted on 6 - $\mathrm{ft}$ (between vines) by $10-\mathrm{ft}$ (between rows) spacing. Approximate row length in the 'Syrah' block was $600 \mathrm{ft}$ and in the 'Merlot' block was $360 \mathrm{ft}$. There were 120 vines per row in 'Syrah' and 60 vines per row in 'Merlot'. Vines were trained to a standard bilateral cordon system with either dual or single trunks, and canopies were managed using the standard modification of vertical shoot positioning that is typical of eastern Washington vineyards. This modification consists of a single set of foliage catch wires $\approx 8$ inches from the cordon wire, and remaining foliage wires placed as single wires rather than in pairs at $\approx 12$-inch intervals from the catch wire set up to the top of the trellis system. This modification results in approximately one-third of the canopy trained upright, with the remaining canopy allowed to partially lie on either side of the trellis. No fruit-zone leaf removal was done in the vineyard. The vineyard was drip-irrigated, with regulated deficit irrigation at $70 \%$ of crop evapotranspiration starting after fruit set. All other vineyard management practices (e.g., weed and pest management, shoot thinning) were conducted under the standard practices defined by the grower.

WEATHER. All weather data were collected through the AgWeathernet weather station system operated by Washington State University (AgWeatherNet, 2014). The weather station nearest the research site was
"Paterson West," located within 1 mile of the vineyard blocks. Growing degree day (GDD) accumulation was calculated from 1 April to 31 Oct. for 2013, using $50{ }^{\circ} \mathrm{F}$ as a base temperature. To calculate GDD units per day, the base temperature was subtracted from the average daily temperature (Amerine and Winkler, 1944). In the event that this calculation resulted in a negative number, the negative number was reset to zero.

Heat treatment application. Heat was applied using an Agrothermal Systems (Walnut Creek, CA) machine (Fig. 1), which generated heat by burning propane. The heated air was projected at $50 \mathrm{mph}$ from the vents toward the vines through a blower. The system was towed by a tractor driven at $4 \mathrm{mph}$. This resulted in a total duration of heat exposure of 1.5 to $2 \mathrm{~s}$ per vine. At the beginning of the study, vents were mounted so that the distance between the vent mouth and vine canopy was 12 to 15 inches; air was directed toward the vine canopy by upward-slanted plates inside the vents. The temperature shown at the vent control panel was verified using an IR thermometer (model 42510A; FLIR Systems, Boston, MA) as well as a thermal imaging camera (model TM400, FLIR Systems).

To determine the actual temperature of the air reaching the vine, a single, controlled study was conducted to better determine the heat distribution radiating from the vents of the unit. This study was conducted in-field on 26 June 2013 and was done independently of a treatment application. This was done in the morning, when ambient temperature was $\approx 64^{\circ} \mathrm{F}$. Four temperature sensors (iButton; Maxim Integrated, San Jose, CA) were mounted on each of two 8 -ftlong bamboo sticks, at $36,48,60$, and 72 inches above the ground. The sensor-mounted sticks were placed between the machine and the canopy at $\approx 7$ and 14 inches from the unit vent (Fig. 2). Temperatures were recorded at $\mathrm{l}$-s intervals before, during, and for $30 \mathrm{~s}$ after the tractor passing. On the basis of these preliminary temperature distribution data, the manufacturer recommended extending the vents of the unit at a $30^{\circ}$ angle and 6 inches closer to the canopy to increase exposure temperatures. This adjustment was done at the end of the bloom

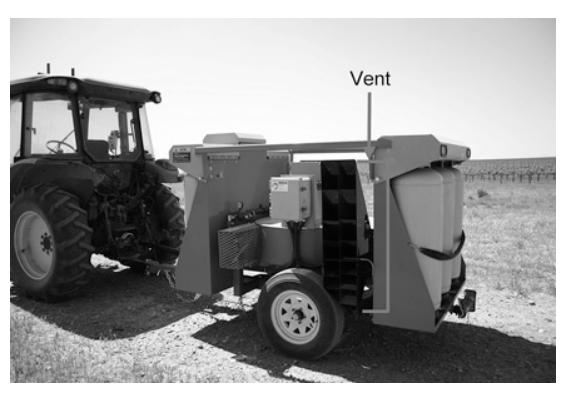

Fig. 1. Transient heat application machine (Agrothermal Systems, Walnut Creek, CA). Heat is applied through angled vents to the wine grape vine canopy and is generated by burning propane gas (Agrothermal Systems, 2013).

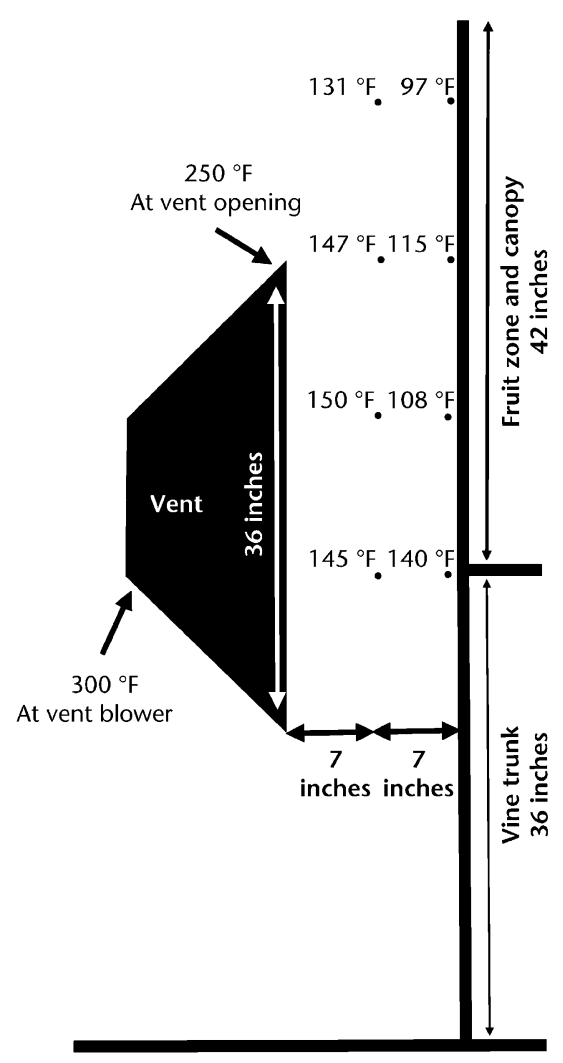

Fig. 2. Distribution of heat between the commercial heat application machine's (Agrothermal Systems, Walnut Creek, CA) vent and the wine grape vine canopy, as measured independently from a treatment application.

Temperature indicated is the singlepoint maximum air temperature that was recorded over $60 \mathrm{~s}$ that encompassed, pre-, during, and posttractor passing. Dots indicate temperature sensors at 7 and 14 inches from the vent at height intervals of 12 inches starting at $\mathbf{3 6}$ inches above the ground. Measurements were done on 26 June 2013 at 8:15 AM and ambient temperature was around $64^{\circ} \mathrm{F} ; 1$ inch $=$ $2.54 \mathrm{~cm},\left({ }^{\circ} \mathrm{F}-32\right) \div 1.8={ }^{\circ} \mathrm{C}$. 
treatment (9 July) and was maintained at this distance and angle for the remainder of the study. The heat distribution from this adjustment was not remeasured after adjustment but is assumed to be similar to the heat measured at 7 inches from the vent (Fig. 2).

VINE DEVELOPMENT AND PHENOLOGY. In each treatment replicate, five sentinel vines were evaluated for phenological development using the $\mathrm{BBCH}$ scale (Meier, 2001). The $\mathrm{BBCH}$ scale is a numerical description of plant growth stages, which uses a two-digit rating scale to specifically delineate key stages in vegetative and reproductive growth. The first digit indicates the key stage of development (i.e., in grapevines, "l" is early shoot and leaf development, " 6 " is flowering, " 8 " is ripening); the second digit indicates how far along within that stage the vine is on a 1 to 9 scale (" 5 " is half way). As an example, BBCH 65 in grapevine indicates that the cluster is half way through flowering/cap fall. In this study, three inflorescences located distally, medially, and proximally to the trunk on each cordon arm (i.e., six inflorescences per vine) were monitored for phenological progression on each sentinel vine. Phenological ratings were taken weekly from prebloom (BBCH 55) until fruit set [BBCH 71 (23 May to 17 June)], biweekly from fruit set until véraison [BBCH 81 (17 June to 30 July)], and weekly from early véraison until preharvest $[\mathrm{BBCH}$ 86 (30 July to 4 Sept.)].

Treatments. Heat application treatments included l) untreated control (Control), 2) heat application during the bloom period only (Bloom) starting 5 to $10 \mathrm{~d}$ before bloom [BBCH 57 (inflorescence developed, flowers separating)] and repeated weekly until fruit set $(\mathrm{BBCH}$ 71),3) heat application during véraison only (Véraison), starting at lag phase $(\mathrm{BBCH} 8 \mathrm{l})$ until $\approx 90 \%$ berry color change (BBCH 86), 4) heat application during both the bloom and véraison periods as described above with additional heat treatment every $14 \mathrm{~d}$ between fruit set and lag phase (Bloom and Véraison); and 5) a standard, full-season heat application from bloom to harvest with heat application weekly from the onset of bloom [BBCH 61 (10\% cap fall)] until harvest (Standard Full). The experiment was designed as a randomized complete block for each variety, with three replicates of the five treatments. A replicate consisted of a single vineyard row with a single buffer row on either side of the treatment row to ensure no extraneous heat "drift." While only one side of the canopy was treated in a single pass, treatments consisted of heating both sides of the canopy (i.e., the alternate side heated on the next pass). Heat treatments were applied in the morning between 6:30 and 8:30 AM. As noted above, the tractor speed of $4 \mathrm{mph}$ resulted in vine exposure to heated air for duration of 1.5 to $2 \mathrm{~s}$. Table 1 contains treatment descriptions and dates of heat treatment application.

LEAF AND CLUSTER HEAT RETENTION. Leaf surface temperature was measured on 11 June in 'Merlot' and 10 July in 'Syrah', while cluster surface temperature was measured after the onset of véraison (21 Aug. for both varieties). In both of the varieties, three heat-treated and three untreated fully expanded leaves, or three clusters per replicate, were arbitrarily selected for temperature measurement. Surface temperature was measured from $\approx \mathrm{l} \mathrm{ft}$ from the desired surface, using an IR thermometer. Temperature was recorded every $2 \mathrm{~s}$, starting $\approx 15$ to $30 \mathrm{~s}$ before heat application, and continuing $60 \mathrm{~s}$ after heat application. Total heat accumulated was calculated by comparing the area under the curve using trapezoidal integration (Burden and Faires, 2000).

FRUIT SET. In both varieties, fruit set was calculated as percent of total berries formed relative to total flowers initially present on the inflorescence (as determined by calyptra counts) using 10 clusters per treatment replicate. Fruit set was calculated in the Control and Bloom treatments only. At this time of the growing season, the Control and Véraison treatments had received the same treatment (i.e., no heat application), and the Bloom, Bloom and Véraison, and Standard Full treatments were identical as well (i.e., having only received heat during bloom). To count fallen calyptras, inflorescences were enclosed within white, nylon-mesh bags at about BBCH 57 (23 May). Bags were removed at $\mathrm{BBCH} 7 \mathrm{l}$ (11 June), and calyptras were counted within 1 week. At $\approx 5$ weeks post fruit set [BBCH 7l (24 July)], the corresponding clusters were collected and individual berries per cluster were counted.

Table 1. Description of the specific application dates in 2013 of the heat treatments applied by a commercial heat application machine (Agrothermal Systems, Walnut Creek, CA) in commercially grown 'Syrah' and 'Merlot' wine grapes in eastern Washington. A tractor speed of $4 \mathrm{mph}\left(6.44 \mathrm{~km} \cdot \mathrm{h}^{-1}\right)$ resulted in an average heat exposure of 1.5 to $2 \mathrm{~s}$ per vine. Total increase in leaf surface temperature was between 10 and $20^{\circ} \mathrm{F}\left(-12.2\right.$ and $\left.-6.7^{\circ} \mathrm{C}\right)$ during this exposure.

\begin{tabular}{|c|c|c|}
\hline Treatment & Description & Dates of application \\
\hline Control & No heat applied & \\
\hline Bloom & $\begin{array}{l}\text { Heat from prebloom }(\text { BBCH } 57)^{z} \\
\text { until fruit set }(\mathrm{BBCH} 7 \mathrm{l})\end{array}$ & 28 May, 4 June, 11 June, 18 June \\
\hline Bloom and Véraison & $\begin{array}{l}\text { Heat from prebloom (BBCH } 57) \\
\text { until fruit set (BBCH } 71) \text { and from lag phase } \\
(\mathrm{BBCH} 81) \text { until } 90 \% \text { véraison (BBCH } 86)\end{array}$ & $\begin{array}{l}28 \text { May, } 4 \text { June, } 11 \text { June, } 18 \text { June, } 25 \text { June, } \\
9 \text { July, } 23 \text { July, } 30 \text { July, } 6 \text { Aug., } 13 \text { Aug. }\end{array}$ \\
\hline Standard Full & $\begin{array}{l}\text { Heat from prebloom (BB6H } 57) \\
\text { until preharvest }(\mathrm{BBCH} 89)\end{array}$ & $\begin{array}{l}28 \text { May, } 4 \text { June, } 11 \text { June, } 18 \text { June, } 25 \text { June, } \\
9 \text { July, } 23 \text { July, } 30 \text { July, } 6 \text { Aug., } \\
\text { and } 13 \text { Aug., } 21 \text { Aug., and } 4 \text { Sept. }\end{array}$ \\
\hline
\end{tabular}

${ }^{{ }^{2} \text { Meier (2001) }}$ 
Fruit SOluble SOlids, PH, AND TA DURING RIPENING. To track soluble solids, $\mathrm{pH}$, and TA, 20 clusters from each treatment replicate were sampled weekly, starting at $\approx 4$ weeks before commercial harvest. The 20 clusters per treatment replicate were collected from both sides of the vine canopy, and from proximal, medial, and distal locations relative to the vine trunk. The 20 clusters per treatment replicate were crushed into a single juice sample for analysis, which is standard procedure for the commercial grower's receiving winery. Soluble solids were measured with a digital handheld refractometer (PR-32 Pallette; Atago U.S.A., Bellevue, WA). The TA and $\mathrm{pH}$ were measured on a radiometer autotitrator (model TIM-850; Hach Co., Loveland, CO); titration was to a $\mathrm{pH}$ endpoint of 8.2 , using $0.1 \mathrm{~N}$ sodium hydroxide (Iland et al., 2000).

Statistical analyses. Data were analyzed using Excel 2010 (Microsoft, Redmond, WA) and ANOVA in JMP 9 (SAS Institute, Cary, NC). Means were separated by Tukey's honest significant difference at $\alpha=0.05$. Data were tested for normality by Shapiro-Wilk test and homogeneity of variance by Levene's test. No variables required transformation.

\section{Results and discussion}

Site Weather. The 2013 vintage was marked by above-normal temperatures and average precipitation. Average monthly high/low temperatures were April $\left(63.7 / 40.0{ }^{\circ} \mathrm{F}\right)$, May $\left(74.9 / 47.7^{\circ} \mathrm{F}\right)$, June $\left(80.7 / 54.4^{\circ} \mathrm{F}\right)$, July $\left(93.5 / 58.8^{\circ} \mathrm{F}\right)$, August (90.5/ $\left.59.3{ }^{\circ} \mathrm{F}\right)$, September $\left(79.8 / 54.3^{\circ} \mathrm{F}\right)$, and October $\left(63.1 / 36.4^{\circ} \mathrm{F}\right)($ Fig. 3A) Growing degree day accumulation on 31 Oct. 2013 was 3086 GDD (base $50{ }^{\circ} \mathrm{F}$ ); average for that same period is 2946 GDD. Total monthly precipitation was April (1.12 inch), May (0.85 inch), June (0.94 inch), July (0.03 inch), August (0.15 inch), September ( 1.25 inch), and October (0.1 inch) (Fig. 3B).

Heat application. Heat distribution from the unit vent is indicated in Fig. 2. Temperatures presented at 7 and 14 inches from the vent are those from a single tractor pass (with temperature data collected every second) and represent the maximum air temperature reached, which typically occurred within 5 to $20 \mathrm{~s}$ of the tractor passing. The temperature at the vent blower, which was measured using an IR thermometer described previously was $\approx 280$ to $310{ }^{\circ} \mathrm{F}(\mathrm{n}=10)$; the temperature at the mouth of the vent was $\approx 230$ to $250{ }^{\circ} \mathrm{F}(\mathrm{n}=10)$. Temperature decrease was directly proportional to the distance from the vent blower. At 14 inches from the vent mouth (Fig. 2), the air temperatures were $140{ }^{\circ} \mathrm{F}$ at the base of the fruiting zone, 108 to $115^{\circ} \mathrm{F}$ in the fruiting zone, and $97^{\circ} \mathrm{F}$ in the upper canopy, which corresponded to a $50 \%$ to $55 \%, 59 \%$ to $65 \%$, and $65 \%$ to $69 \%$ decrease from the temperature at the vent blower, respectively. Considering the ambient temperature of $64^{\circ} \mathrm{F}$, the actual increase in the ambient temperature when the vent mouth was 14 inches from the canopy was around 44 to $51{ }^{\circ} \mathrm{F}$ in the fruit zone and $33{ }^{\circ} \mathrm{F}$ in the upper canopy (Fig. 2). Given this distribution of temperature when the vent mouth was 14 inches from the canopy (Fig. $2)$, the manufacture added a six-inch extension for the vent mount to increase the change in immediate air temperature around the canopy and fruit zone. Assuming this would result in a temperature pattern that would be similar to that seen at 7 inches from the vent mount (as measured and depicted in Fig. 2), this would have raised ambient temperatures by 83 to $86^{\circ} \mathrm{F}$ in the fruit zone and $67^{\circ} \mathrm{F}$ in the upper canopy.

LEAF AND CLUSTER HEAT RETENTION. In 'Syrah', average heat accumulation over time (above a base, accumulated over $60 \mathrm{~s}$ ) in leaves was significantly greater in the heattreated $\left(332{ }^{\circ} \mathrm{F}\right)$ compared with the untreated control $\left(11{ }^{\circ} \mathrm{F}\right)(P=$ 0.002 ). In 'Merlot', average heat accumulation in the heat-treated leaves $\left(158{ }^{\circ} \mathrm{F}\right)$ was significantly greater than the untreated control $\left(37^{\circ} \mathrm{F}\right)(P=0.001)$. In 'Syrah', the average heat accumulation in heattreated clusters $\left(166^{\circ} \mathrm{F}\right)$ was significantly greater compared with the untreated control $\left(-1{ }^{\circ} \mathrm{F}\right)(P=$ $0.003)$. A similar result was seen in 'Merlot', where average heat accumulation in heat-treated clusters $\left(101^{\circ} \mathrm{F}\right)$ was significantly greater than the untreated control $\left(-11{ }^{\circ} \mathrm{F}\right)(P=$ $0.004)$. However, in either variety, the maximum change in leaf or cluster surface temperature was 10 to $20^{\circ} \mathrm{F}$ for 10 to $20 \mathrm{~s}$ (Fig. 4A and B). Cluster and leaf surface temperature approached that of the control within 60 s. Heat-treated clusters (Fig. 4B) had initial cooler surface temperature measurements as a result of timing of temperature recording relative to the control (treatment observations separated by $20 \mathrm{~min}$ ) and rapid increase in daytime temperature. In addition, while a temperature spike was evident in the heat-treated clusters (Fig. 4B), individual cluster temperatures were variable due to their location (shaded or sun exposed). Overall, the difference in temperature retention (i.e., heat accumulation) between control and heat-treated clusters was less than that seen in leaves; this is likely due to the mass difference between these two organs. Near véraison, a cluster has significantly higher mass than an individual leaf, thus requiring more energy to induce a substantial change in temperature.

Leaf and cluster heat accumulation by the heat treatments was similar to natural heating by the sun in

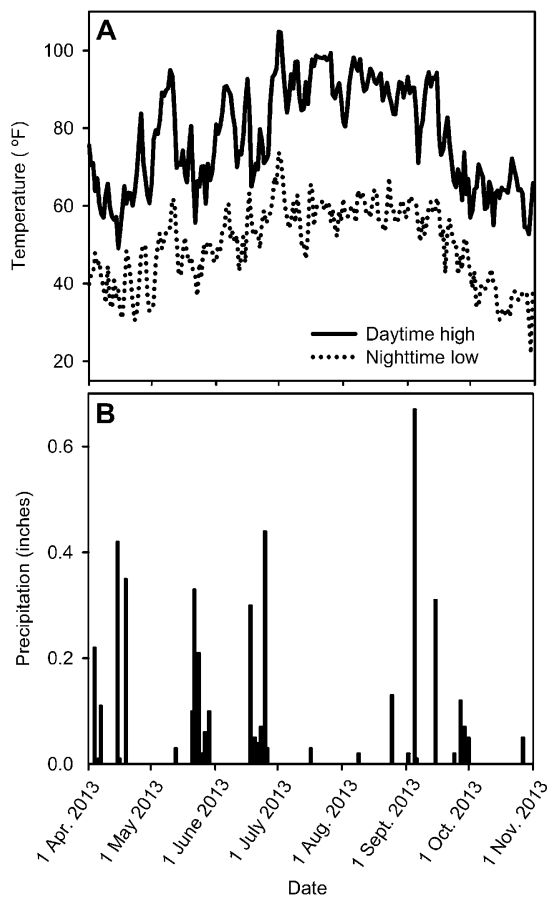

Fig. 3. (A) Daily maximum and minimum temperature and (B) daily precipitation from 1 April to 31 Oct. 2013 as recorded by the "Paterson West" AgWeatherNet weather station (AgWeatherNet, 2014); 1 inch $=2.54 \mathrm{~cm}$, $\left({ }^{\circ} \mathrm{F}-32\right) \div 1.8={ }^{\circ} \mathrm{C}$. 
the afternoon (Smart, 1985; Spayd et al., 2002; Tarara et al., 2008). For example, natural solar heating on 21 Aug. 2013 between 1:00 and 2:00 PM resulted in heat accumulation that averaged $160^{\circ} \mathrm{F}$. This natural heating was a result of $5.3{ }^{\circ} \mathrm{F}$ change in ambient air temperature (82.3 to $87.6{ }^{\circ} \mathrm{F}$ ) during that $\mathrm{l}$-h period. While the additional heat applied by the machine occurred in the morning, it is transient and lower than the natural heating of the grapevines in the afternoon in eastern Washington's climate.

There are several modifications that may improve heat retention of vine canopy, and these include adjusting vents to be closer to the canopy to increase air temperature (as was done during bloom in this study), delaying application until later in the morning to slow the loss of heat by reducing the air temperature differential, and slower tractor speed at the time of

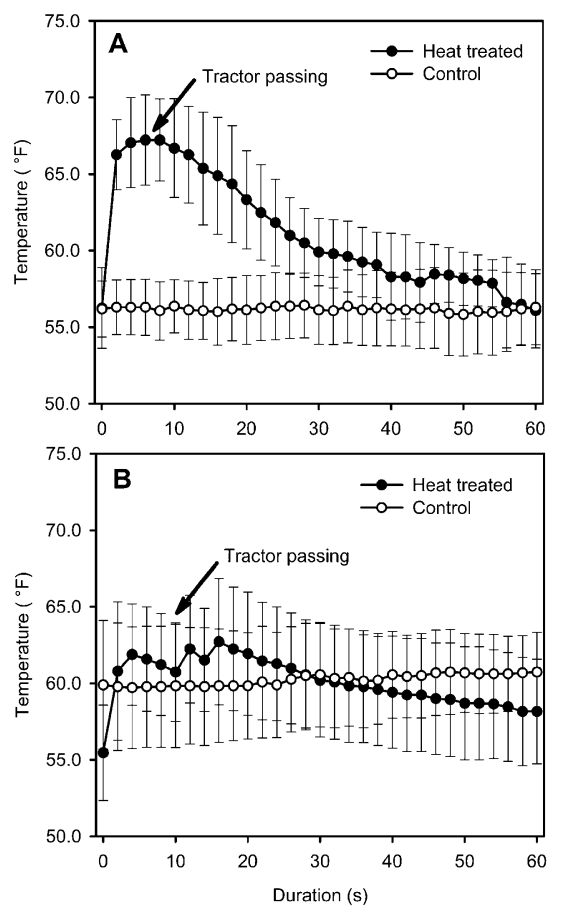

Fig. 4. Temperature dynamics of wine grape (A) 'Merlot' leaves on 11 June 2013 and (B) 'Syrah' clusters on 21 Aug. 2013 before, during, and after heat application via a commercial heat application machine (Agrothermal Systems, Walnut Creek, CA). The temperatures plotted are from an average of three heat-treated and untreated units, represented by solid and open circles, respectively. Error bars represent SE; $\left({ }^{\circ} \mathrm{F}-32\right) \div 1.8={ }^{\circ} \mathrm{C}$. application to increase the duration of heat exposure. Caution should be taken with adjustments so that they do not result in direct and extended high temperature exposure that could potentially damage leaves or fruit.

VINE DEVELOPMENT AND PHENOLOGY. Bloom (BBCH 65), defined as $50 \%$ cap fall in $50 \%$ of the clusters, was on 8 June 2013 in 'Merlot' and on 1 June 2013 in 'Syrah', regardless of treatment. In addition, heat application during bloom did not abridge the duration from the onset until complete bloom (BBCH 61 to 69$)$ in either variety. The onset of véraison was on 2 Aug. 2013 in 'Merlot' and on 10 Aug. 2013 in 'Syrah', regardless of treatment. Heat application between bloom (BBCH 65) and véraison (BBCH 86) (28 May to 21 Aug.), and at the onset of véraison did not advance or abridge the timing and duration of véraison $(\mathrm{BBCH} 81$ to 86). Commercial harvest of the fruit was on 5 Oct. 2013 for both the varieties and all treatments.

FruIT SET. In 'Merlot', heat application during bloom did not affect the number of berries per cluster or fruit set when compared with the control $[P=0.92$ and 0.30 , respectively (Table 2)]. Fruit set averaged $28 \%$ in the Bloom treatment and $31 \%$ in the Control treatment (Table 2). Similarly in 'Syrah', there was no difference in the number of berries per cluster or fruit set between heat application treatment during bloom and the control $[P=0.51$ and 0.93 , respectively (Table 2 )]. Fruit set averaged $59 \%$ in both the Bloom and Control treatments. The commercial vineyard reported that final harvest yields in 2013 were 2.8 tons/acre for 'Merlot' and 3.4 tons/acre for 'Syrah'.

Fruit soluble solids, $\mathrm{PH}$, AND TA DURING RIPENING. In 'Merlot', heat application, regardless of timing, did not affect final juice soluble solids $(P=0.94)$, TA $(P=0.31)$, or $\mathrm{pH}(P=$ $0.90)$ (Table 3 ). Similarly in 'Syrah', heat application, regardless of timing, did not affect final juice soluble solids $(P=0.22)$, TA $(P=0.45)$, or $\mathrm{pH}(P=$ 0.41 ) (Table 3).

Exposure to high temperatures $\left(>95^{\circ} \mathrm{F}\right.$ ) during ripening can negatively impact sugar accumulation and TA (Gu et al., 2012; Kliewer, 1977). Heating of plant tissue, such as leaves or clusters, requires considerable energy input in terms of heat transfer by moving air, or convection and radiation (Smart, 1985). Thus, transient and small changes in temperature such as those observed in this study are unlikely to advance phenology or other biochemical processes relative to the changes that would be induced by other environmental stresses (i.e., water stress, naturally occurring heat stress). For example, the temperature of sun-exposed berries could easily increase by 10 to $20{ }^{\circ} \mathrm{F}$ compared with ambient temperature if vines are also under water stress (Smart, 1985); similar increases are also seen in sun-exposed berries (Bergqvist et al., 2001; Spayd et al., 2002; Tarara et al., 2008). Regulated deficit irrigation at $70 \%$ of crop evapotranspiration after fruit set is a standard practice in eastern Washington. Combined with naturally occurring diurnal temperature changes

Table 2. Effect of transient heat application during the bloom on average number of berries per cluster and fruit set in 'Syrah' and 'Merlot' wine grapes. Fruit set was determined as a percent of total berries per cluster relative to total calyptras collected per inflorescence. Clusters evaluated were from the Bloom heat treatment application (received heat application over the bloom period), and from the Control treatment (no heat during the bloom period). At the time of evaluation, the Bloom, Bloom and Véraison, and Standard Full treatments had received the same number of heat treatments, whereas the Control and Véraison treatments had not received heat treatments. No statistical differences were found between treatments on each date using Tukey's honest significant difference at $\alpha=0.05(n=30)$.

\begin{tabular}{llcc}
\hline Variety & Treatment & $\begin{array}{c}\text { Berries per cluster } \\
{[\text { mean } \pm \text { SD (no.) }}\end{array}$ & $\begin{array}{c}\text { Fruit set } \\
{[\text { mean } \pm \text { SD (\%)] }}\end{array}$ \\
\hline Syrah & Control & $144 \pm 20$ & $59 \pm 5$ \\
& Bloom & $153 \pm 6$ & $59 \pm 3$ \\
Merlot & Control & $109 \pm 4$ & $31 \pm 3$ \\
& Bloom & $110 \pm 16$ & $28 \pm 2$ \\
\hline
\end{tabular}


Table 3. Effect of transiently applied heat during different times of the growing season using a commercial heat application machine (Agrothermal Systems, Walnut Creek, CA) on soluble solids, titratable acidity, and pH from post-véraison to harvest in commercially grown 'Syrah' and 'Merlot' wine grapes in 2013 in eastern Washington. Treatments consisted of heat application during Bloom, Bloom and Véraison, Véraison, or over the course of the summer (Standard Full), and a Control (untreated) as described in Table 1. No statistical differences were found between treatments on each date using Tukey's honest significant difference at $\alpha=0.05(n=20)$.

\begin{tabular}{|c|c|c|c|c|c|c|c|c|c|}
\hline \multirow[b]{2}{*}{ Treatments } & \multicolumn{3}{|c|}{ Soluble solids (\%) } & \multicolumn{3}{|c|}{ Titratable acidity $(\mathrm{g} / 100 \mathrm{~mL})^{\mathrm{z}}$} & \multicolumn{3}{|c|}{$\mathrm{pH}$} \\
\hline & 19 Sept. & 27 Sept. & 3 Oct. & 19 Sept. & 27 Sept. & 3 Oct. & 19 Sept. & 27 Sept. & 3 Oct. \\
\hline \multicolumn{10}{|c|}{ 'Syrah’ } \\
\hline Bloom & 22.6 & 23.1 & 23.6 & 0.47 & 0.43 & 0.39 & 3.45 & 3.55 & 3.50 \\
\hline Bloom and Véraison & 23.4 & 22.8 & 23.6 & 0.45 & 0.46 & 0.40 & 3.48 & 3.51 & 3.52 \\
\hline Véraison & 23.0 & 23.0 & 23.6 & 0.46 & 0.42 & 0.40 & 3.46 & 3.51 & 3.53 \\
\hline \multicolumn{10}{|c|}{ 'Merlot' } \\
\hline Control & 24.2 & 23.8 & 23.0 & 0.44 & 0.44 & 0.34 & 3.45 & 3.54 & 3.42 \\
\hline Bloom & 24.0 & 23.6 & 24.3 & 0.40 & 0.36 & 0.38 & 3.46 & 3.44 & 3.53 \\
\hline Bloom and Véraison & 24.0 & 24.0 & 23.5 & 0.40 & 0.39 & 0.37 & 3.46 & 3.47 & 3.48 \\
\hline Véraison & 24.2 & 24.3 & 23.7 & 0.39 & 0.44 & 0.32 & 3.47 & 3.56 & 3.40 \\
\hline
\end{tabular}

${ }^{\mathrm{z}} 1 \mathrm{~g} / 100 \mathrm{~mL}=1 \%$.

Table 4. Additional cost-per-application of applying each heat treatment using a commercial heat application machine (Agrothermal Systems, Walnut Creek, CA) in commercially grown 'Syrah' and 'Merlot' wine grapes in eastern Washington. Treatments consisted of heat application during Bloom, Bloom and Véraison, Véraison, or over the course of the summer (Standard Full), and an untreated Control as described in Table 1 . Costs were calculated using input calculations for man-hours, tractor diesel, and propane used, and were supplied by the participating vineyard.

\begin{tabular}{llccr}
\hline Variety & \multicolumn{1}{c}{ Treatment } & $\begin{array}{c}\text { Cost per application } \\
(\$ / \text { acre })^{\mathbf{z}}\end{array}$ & $\begin{array}{c}\text { Heat } \\
\text { applications (no.) }\end{array}$ & $\begin{array}{c}\text { Total cost } \\
(\$ / \text { acre })\end{array}$ \\
\hline Syrah & Control & 16.20 & 0 & 0.00 \\
& Bloom & 4 & 64.80 \\
& Bloom + Véraison & 10 & 162.00 \\
& Véraison & 3 & 48.60 \\
& Standard Full & & 12 & 194.40 \\
\multirow{2}{*}{ Merlot } & Control & & & \\
& Bloom & 18.90 & 4 & 0.00 \\
& Bloom + Véraison & & 10 & 75.60 \\
& Véraison & 3 & 189.00 \\
& Standard Full & 12 & 56.60 \\
\hline
\end{tabular}

${ }^{\mathrm{z}}$ Cost per application includes cost of labor, tractor, propane, and administration. Difference in cost per acre in 'Syrah' and 'Merlot' wine grape was due to the length of row. Shorter rows in 'Merlot' compared with 'Syrah' required frequent tractor turns, increasing the time and application cost per acre; $\$ 1 /$ acre $=\$ 2.4711 / \mathrm{ha}$.

during the months of ripening, deficit irrigation and sun exposure are likely to have a larger influence on grape berry ripening than transient, small temperature changes seen here with machine-applied heat.

The average cost for a single heat application was between $\$ 16.20$ and $\$ 18.90$ per acre, depending on vineyard size (Table 4). Shorter rows in the 'Merlot' block required more tractor turns per acre, hence, more time for the operator and higher overall application cost on a per-acre basis. Given the total cost multiplied over hundreds of acres and the need for multiple passes, coupled with the lack of dramatic response, the commercial operation chose to not continue using the machine for future vintages at this location.

In conclusion, overall results suggest that transient heat application may not be an effective tool to advance phenology or to improve fruit and thus wine quality in eastern
Washington due to vineyard practices and environmental stresses that may override the transient heat imposed by the heat system.

\section{Literature cited}

Agrothermal Systems. 2013. Heat treatment offers wine growers better production. 6 May 2014. <http:// agrothermalsystems.com $>$.

AgWeatherNet. 2014. Historic climate summary-WSU HQ weather station. 6 May 2014. <http:// weather.wsu.edu>.

Amerine, M.A. and A.T. Winkler. 1944. Composition and quality of musts and wines of California grapes. Hilgardia 15:493-673.

Bergqvist, J., N. Dokoozlian, and N. Ebisuda. 2001. Sunlight exposure and temperature effects on berry growth and composition of Cabernet Sauvignon and Grenache in the central San Joaquin Valley of California. Amer. J. Enol. Viticult. 52:1-7.

Burden, R.L. and J.D. Faires. 2000. Numerical analysis. 7th ed. Brooks-Cole, Belmont, CA.

Ferguson, J.C., J.M. Tarara, L.J. Mills, G.G. Grove, and M. Keller. 2011. Dynamic thermal time model of cold hardiness for dormant grapevine buds. Ann. Bot. (Lond.) 107:389-396.

Gu, S., S. Jacobs, B. McCarthy, and H.L. Gohil. 2012. Forcing vine regrowth and shifting fruit ripening in a warm region to enhance fruit quality in 'Cabernet Sauvignon' grapevines (Vitis 


\section{Preliminary and Regional Reports}

vinifera L.). J. Hort. Sci. Biotechnol. 87:287-292.

Iland, P., A. Ewart, J. Sitters, A. Markides, and N. Bruer. 2000. Techniques for accurate chemical analysis and quality monitoring during winemaking. Wine Promotions, Campbell Town, Australia.

Jackson, D.I. and N.J. Cherry. 1988. Prediction of a district's grape ripening capacity using latitude-temperature index (LTI). Amer. J. Enol. Viticult. 39:19-28.

Jackson, D.I. and P.B. Lombard. 1993. Environmental and management practices affecting grape composition and wine quality: A review. Amer. J. Enol. Viticult. 44:409-430.

Jackson, R.S. 2008. Wine science: Principles and applications. Elsevier-Academic Press, Burlington, MA.
Keller, M. 2010. The science of grapevines: Anatomy and physiology. ElsevierAcademic Press, Burlington, MA.

Kliewer, W.M. 1977. Influence of temperature, solar radiation, and nitrogen on coloration and composition of Emperor grapes. Amer. J. Enol. Viticult. 28:96-103.

Meier, U. (ed.). 2001. Growth stages of mono- and dicotyledonous plants. $\mathrm{BBCH}$ Monogr. Blackwell Wissenschafts-Verlag, Berlin, Germany.

Smart, R. 1985. Principles of grapevine canopy microclimate manipulation with implications for yield and quality. A review. Amer. J. Enol. Viticult. 36:230-239.

Spayd, S.E., J.M. Tarara, D.L. Mee, and J.C. Ferguson. 2002. Separation of sunlight and temperature effects on the composition of Vitis vinifera cv. Merlot berries. Amer. J. Enol. Viticult. 53:171182.
Tarara, J.M., L. Jungmin, S.E. Spayd, and C.F. Scagel. 2008. Berry temperature and solar radiation alter acylation, proportion, and concentration of anthocyanin in Merlot grapes. Amer. J. Enol. Viticult. 59:235-247.

U.S. Department of Agriculture. 2013. Non-citrus fruits and nuts: 2012 preliminary summary. I May 2014. <http:// usda.mannlib.cornell.edu/usda/current/ NoncFruiNu/NoncFruiNu-01-252013.pdf>.

Yau, I.-H., J.R. Davenport, and M.M. Moyer. 2014. Developing a wine grape site evaluation decision support system for the inland Pacific Northwest. HortTechnology 24:88-98. 